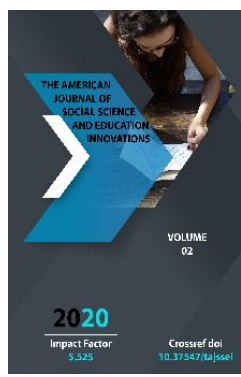

\title{
The Issue Of Attitude Towards Women In Boburnoma
}

\author{
Kosimova Gulsanam \\ Lecturer Of The Department Of Foreign Languages, Fergana State University, Uzbekistan
}

Copyright: Original content from this work may be used under the terms of the creative commons attributes 4.0 licence.

\section{ABSTRACT}

The author of "Boburnoma" describes about the historical figures of his time: rulers, cultural and artistic figures, their position in society, and provides information about their marital status. The book focuses on how their wives, their children's behaviors and clarifies the author's conclusions about the family as an integral part of society, his views on the influence of the family in determining the place of any person in social life. In this article, I will discuss the author's progressive views on his time, in particular, his views on women and their role in society.

\section{KEYWORDS}

Boburnoma, Babur, women,

\section{INTRODUCTION}

Many historical sources and works of art provide us almost no information about the personality and activities of women according to Eastern etiquette and Islamic beliefs. Even their names are not fully mentioned. AlisherNavoi, for example, does not mention the names of Hussein Boykaro's palace and the women in his official circles. He only mentions Khadijabegi in a few places as "Mahdi Ulyo" the mother of the heir to the throne. The same can be said about the works of such historians as Mirkhand, Khandamir, Davlatshah Samarkandiy, who belonged to the time of Babur. 
However, the work of Zahiriddin Muhammad Babur "Boburnoma" is unique and noteworthy in the regard. The king and the poet also dwell on the famous and the women of his time, the Timurid dynasty and the women in the family of Umarshaikh Mirza to whom he belonged. When he mentions them as historical figures, he is telling the truth about his character, manners, and even his influence on the affairs of the kingdom.

He also talks in detail about the women in the house of Umarshaikh Mirza, where he was born and raised. Umarshaikh Mirza's descendants: three sons and five daughters. Greater than all the sons of Bori- I was Zahiriddin Muhammad Babur. My mother was Kutluq Nigorkhanim. Another son was JahongirMirza, who was two years younger than me, whose mother was one of the Mongol district beys, Fatima Sultan on horseback. Another son was NasirMirza, his mother was from Andijan, he was a concubine, Umid was a horseman.

Bori was the greatest of my daughters, she was my cousin, she was five years older than me. Another girl was Shahrubonubegim, her mother was YodgorSultanbegim, her mother was Agacha Sultan, a horseman.[1.12]

It is clear from the passage quoted that while introducing the reader to the women in his family, Babur also mentions their names, origins, when they were born, and the fate of their future.

For Baburshah, the honor and dignity of the family, especially mothers, sisters and daughters, is sacred. That is why he speaks with hatred of the deeds of MirzaBadiuzzaman and MirzaMuzaffar, who fled their captives to the hands of their enemies. When Shaybanikhan invaded, he said "I was in Ihtiyoriddin, the mother and the owner of the mirzas, and the wives and sisters of the mirzas, the wives of the mirzas. They can not imagine the fortress itself. In the midst of so many opportunities and opportunities, the mother and the owner-sister, as well as the nomads and the sons-in-law, are taken away and left in Uzbek captivity..."[1.185]

Babur also strongly condemns his vicious enemy, Shaybanikhan for his inhumane treatment of women. Although Babur himself did not like Khadijabegi, he criticized Shaybaniykhan for his unjust actions towards him: Rustoi and the man in the nod, the world has won a bad horse for the five-day past. First of all, for the sake of Khadijabeg on the lift of the bakhshi and made all kinds of hardships...[1,186]

During the details of the events about Hussein Boykaro, the ruler of the Khorasan kingdom, Boburmirzo also gives interesting information about his wives and daughters. He also talks about the behavior of the ladies of the palace, their place in the palace, their position in sociopolitical life. For example, speaking of Hussein Boykaro's wife, Cholibegim, “he knew a lot about his eloquence". There was no word, he said".

Beka Sultan Beg, the daughter of SanjarMirzaMarvi, another wife of Sultan Hussein Bayqara. The author of "Boburnoma" about this woman was very bad-tempered. Sultan Hussein Mirza was devastated by his cruelty, put an end to it and was saved. This is followed by the following Persian byte:

Zani bad darsaroyimardinako', Hell is the lowest hell in the universe. 
Translation: The bad wife in the house of a good man is his hell in this world itself. The author of the Boburnoma adds after verse: "May God never inflict this balloon on any Muslim. Let not a wicked woman remain in the divine world. [1.152]

The talented poet, one of the translators of Babur's persian poems, TalibNasir, translated it into uzbek as follows:

The bad wife in the castle of a good husband, The earth is hell, and the earth is wood[6.29]

Another wife of Sultan Hussein was ShahribonuBegim, who was the daughter of Abu Said Mirza. Although this woman is considered to be Zahiriddin Muhammad Babur, Babur openly says, that he is very proud and arrogant. During the Chekmon War, when the ladies of the palace came down from the mahofa(board) and rode on horseback, he did not do so. When Hussein heard this, he divorced her.

The most important information in "Boburnoma" is about Khadichabegim. "It simply came to our notice then. Sultan Abusaid was Mirza's concubine. In Iraq Sultan Abu Said came to Herat after the injury(destruction) of Mirza. In Herat, Sultan Hussein received and loved Mirza, who developed from an concubine to a caretaker. Then it was a matter of choice. Muhammad Mumin was killed by his efforts. The sons of Sultan Hussein Mirzafell(turned into savages), more than that. She was sensible, and greedy woman. It is also Rafiziya(Shia)."[1.187]

Babur mentions Hussein Mirza's wife, Opaqbegim, with deep respect. Her devotion to her husband tells the thrilling story of how she raised her adopted childern with genuine love, even though she was childless. Hussein Mirza states that after the fall of his kingdom, this woman came to him and respected him as much as he could: "I had Opoqbegim again, and she had no sons or daughters. Popo kept the trees' sons as his sons. In Mirza's displeasure he served very well, and none of his wives could serve him much. The next year I came to India from Herat. I also bowed and paid my respects."[1.151]

Respect for parents and love for relatives are also branches of boundless devotion to the motherland. Babur's father, UmarshaikhMirza, speaks of his good qualities, such as his extreme honesty and contempt for others. For example, a large caravan from Chine was hit by an avalanche in the Andijan region, and only two out of two hundred people survived. UmarshaihkMirza carefully guarded the caravan's cargo, found the relatives of the dead and handed over the goods to the heirs in full.

Zahiriddin Muhammad Babur, who learned his father's lesson, has made such honesty his motto all his life. It is known that Babur, the commander, established a very strict discipline among his army. Those who wronged the people unjustly never forgave the robbers. In a palace called Oqsaroy, an old woman from the local community brutally beats a navkar who snatched a jug of oil. In the village of Yom, the commander orders his navkars to return the items and equipment confiscated from the residents by dawn.

His respect for his mother, KutlugNigorkhanim, is also an example for the younger generation. When he leaves his homeland, he gives his 
mother a tentand spends a few mornings in the tent with his navkars. Before capturing Kabul, when his mother died, he bought a smaller garden with all his money and buried his mother there. This was what his mother had done, wanting eternal rest on her property. In the events of 1505-1506, the grief and sorrow of Babur, whose mother died as a child, was very vividly expressed: "In the month of Muharram, my mother, KutluqNigor, became ill with diarrhea.

They corrupted, it was a flaw. There was a doctor from Khorasan, Said was a doctor. Khorasan gave the Hindu with the program, because he was dying, and six days later he went to the mercy of the gods on Saturday (died).... During these days of mourning, the little khan heard my father Olachakhon and my great mother EsanDavlatbegim (deceased) in the manga. When my mother was approaching forty, Shahbegim, the mother of the Khurasandin khans, and my aunt MehrNigor came. The mourners were clean, and the grass was clean,"[1.141]

There are reports in history that kings were the guardians of great sheiks. For example, AlisherNavoi'sNasoyim -ulMuhabbat tells of Sheikh SayfiddinBokharzi being ridden by a ruler. When Mir Alisher himself finished writing Hamsa, kingHussein Boykaro mounted him and rode around the streets of Herat in front of the crowd. But in the history of the countries of the East there are no kings who respect a woman and subdue her. The first and the last in this regard is Zahiriddin Muhammad Babur. According to the poet's daughter Gulbadanbegim, when the king's wife, MohimBegimwas was summoned from Kabul to India, Babur walked a few miles to meet her, and the princess, holding the reigns of her horse, returned to the capital on foot. It can also be said that it was a symbol of the great king and the great poet's deep respect for his wife, and therefore for his faithful compatriot, who brought the homeland together. Indeed, Zahiriddin Muhammad Babur has written a number of rubais(quatrains) that express this meaning, and we consider it appropriate to quote one of them:

I will inevitably say a word to you,

I glorify you in the world,

God willing, this service If you do

I wish you all the best.[3.91]

\section{CONCLUSION}

In short, the author of "Boburnoma" for a lifetime tried to tell the truth and truth, raised the banner of justice, made a name for himself as kind to friends, ruthless to enemies, and at the same time respected his human qualities. He valued everyone for their ability, humanity, and good qualities, regardless of nationality, religious beliefs, social background, or gender. He tried to be a personal example to his relatives, children, family, and people around him. Thus, as a great king and commander, poet and cultural figure, scholar and sage, he was able to take an eternal place in the hearts of future generations.

\section{REFERENCES}

1. Babur Zahiriddin Muhammad. "Boburnoma". T.:1990.

2. Babur Zahiriddin Muhammad. “Devon". T.:1994.

3. Nuritdinov $M$. The Baburi dynasty. T.:1994.

4. TolibNosir. "Translation of the Persian Poems in the Boburnoma. Fergana. 2017. 
The American Journal of Social Science and Education Innovations (ISSN - 2689-100x)

Published: December 28, 2020 | Pages: 209-213

Doi: https://doi.org/10.37547/tajssei/Volumeo2Issue12-37

5. Humoyunnoma. T.:1998. 